EESTI NSV TEADUSTE AKADEEMIA TOIMETISED. VII KÖIDE

BIOLOOGILINE SEERIA. 1958, NR. 3

ИЗВЕСТИЯ АКАДЕМИИ НАУК ЭСТОНСКОЙ ССР. ТОМ VII

СЕРИЯ БИОЛОГИЧЕСКАЯ. 1958, № 3

\title{
PÓLEVKIVI LENDTUHA JA TAHMA TOIMEST KATSELOOMADE ORGANISMISSE
}

\author{
A. VÓSAMÄE, \\ meditsiiniteaduste kandidaat
}

Linnade ja tööstuspiirkondade atmosfäärse ōhu sanitaarne kaitse suitsheidistega saastumise vastu on tänapäeva kommunaalhügieeni aktuaalsemaid probleeme. Atmosfäärse ōhu saastumine on üheks väliskeskkonna teguriks, mis avaldab tervist kahjustavat toimet inimorganismisse.

Linnade ja tööstuspiirkondade atmosiäärse ōhu saastumise peamiseks allikaks on mitmesuguste kütuste pōletamisel tööstusettevōtete, elu- ja ühiskondlike hoonete korstnatest väljuvad suitsheidised. G. Seleihovski $\left.{ }^{[28}\right]$ andmetel on tänapäeva tööstuslinnade õhk keskmiselt 25-50 korda tugevamini suitsust saastunud kui neid ümbritsevates rohelistes alades. Nii näiteks teatakse Glasgow', Londoni ja Leeds'i kohta, et seal $1 \mathrm{~m}^{2}$ pinnasele langeb ööpäeva jooksul kuni 1000 ja enam mg tuhka, tahma ja tolmu [28]. Chicago kõige suitsusemates rajoonides on talveperioodil $1 \mathrm{~m}^{2}$ pinnasele ōhust sadestuvate suitsuosakeste hulk $2000 \mathrm{mg}$ piirides ööpäeva kohta. Sverdlovskis on linna keskrajoonides ööpäevanę ōhust sadestuvate suitsuosakeste kogus $2000-2500 \mathrm{mg} 1 \mathrm{~m}^{2}$ kohta [23].

Suitsheidised, mis paisatakse korstnatest atmosfäärsesse ōhku, vôivad koostiselt olla mitmesugused. Suits on segu mitmesugustest gaasidest $\left(\mathrm{CO}_{2}, \mathrm{CO}\right.$, veeaurud, gaasilised väävliühendid jm.), milles väiksemal vôi suuremal hulgal on suspendeeritud tahkeid osakesi - lendtuhka, tahma jm. $\left.{ }^{28}\right]$. On teada, et suitsu mitmesuguste koostisosade hulk ja omavaheline suhe sōltuvad põletatava kütuse hulgast ning kvaliteedist ja kütterežiimist.

Suitsu üheks peamiseks kcostisosaks on lendtuhk. Viimast tekib seda enam, mida rohkem sisaldab kütus mineraalosi. V. Rjazanovi $\left.{ }^{22}\right]$ järgi annavad suitsus kōige kōrgemaid tuhakontsentratsioone madalakalorilised mineraalidest rikkad söeliigid. Eriti kõrge on suitsu tuhakontsentratsioon pōlevkivi pôletamisel. Peale tuha leidub suitsus kütuste orgaanilise osa mittetäielikul pōlemisel tekkinud produkte - tahma ja tôrvolluseid. Nii ühe kui teise sisaldus on seda suurem, mida mittetäielikum on kütuste pōlemine [ ${ }^{24}$, seega eriti niisuguste kütuseliikide puhul, mis sisaldavad rohkesti mineraalaineid (näiteks põlevkivi), iseäranis nende põletamisel harilikkudes küttekolletes [1].

Inimorganismisse toimivad suitsu koostisosad nii kaudselt kui ka otseselt.

Suitsu kaudne tervist kahjustav toime avaldub mikrokliima muutuste tagajärjel. Atmosfääri suitsusus pōhjustab paikkonna mikrokliima halvenemist: tổuseb-uduste päevade sagedus, väheneb atmosfäärse ōhu läbipaistvus, ultraviolettkiirte radiatsioon ning üldse päikesevalguse intensiivsus, muutub õhu elektriline seisund -jm. V. Rjazanovi $\left[{ }^{22}\right]$ andmetest nähtub, et suurlinnades on talveperioodil esinevate uduste päevade arv viimaste aastakümnete jooksul märgatavalt suurenenud. Selle põhjuseks peab autor õhu suurenenud saastumist seoses küttekollete ja kütuse tarbimise rohkenemisega kiiresti kasvavates linnades.

Eespool märkisime, et atmosfääri suitsusus pổhjustab kohalike meteoroloogiliste tingimuste halvenemist udude sagenemise näol. Udud aga omakorda soodustavad ühelt poolt tahkete suitsuosakeste kogunemist atmosfääri alumistesse kihtidesse ning nende sadestumist maapinnale, teiselt poolt kahjulike gaasiliste väävliühendite kontsentratsiooni tōusu 
atmosfääris $\left[{ }^{7},{ }^{22}\right]$ jt. Nii näiteks on täheldatud Londoni ōhus udu ajal gaasilisi väävliühendeid sellistes kontsentratsioonides, mis pōhjustasid elanikel hingamisteede ärritusnähte. Eriti tugevasti avaldusid need isikutel, kes põdesid hingamisteede haigusi [7].

Oheks tõenduseks suitsheidistega saastunud atmosfäärse õhu tervist kahjustava toime kohta on linnaelanike märgatavalt kōrgem suremusprotsent hingamisorganite haigustesse, võrreldes maaelanikega. M. Pannetier' [ ${ }^{6]}$ andmetel oli elanikkonna suremus hingamisteede haigustesse (pneumooniasse, bronhiiti jm.) 1952. aastal Prantsusmaal 100000 elaniku kohta järgmine: 100000 (ja üle selle) elanikuga linnades 120,65; 50000 (ja alła selle) elanikuga linnades vastavalt 95,12 ; maaelanikkonna hulgas aga 78,15 .

Suitsuosakeste otsene kahjustav toime inimorganismisse avaldub hingamiselundite mitmesugustes patoloogilistes protsessides, mis tekivad suitsu koostisosade sattumisel kopsudesse ōhu sissehingamise teel.

Asjaolu, et koos muude suitsheidistega paisatakse atmosfääri rohkesti lendtuhka, on üks peamisi pōhjusi, miks suurlinnade ōhust sadestuv tolm koosneb eeskätt mineraalainetest. Nii on Moskva Erismani-nimelise Sanitaarkaitse ja Hügieeni Instituudi andmetel ōhust sadestuvas tolmus mineraalaineid $63-68 \%$ kogu kaalust $\left.{ }^{22}\right]$. Tööstusrajoonides, kus atmosfäärne õhk on suitsheidistest tugevasti saastunud, täheldatakse kohalikel elanikel kopsude tihenemist sidekoe rohkenemise arvel (fibroos-koniootilised muutused) $\left[{ }^{15}, 20\right.$, ${ }^{23},{ }^{29} \mathrm{jt}$.]. Kopsude fibroossete muutuste tekke seisukohalt omab esmajärgulist tähtsust vaba ja seotud $\mathrm{SiO}_{2}$ hulk atmosfäärses tolmus: mida rohkem leidub ōhus vaba ja seotud $\mathrm{SiO}_{2}$, seda suurem on oht kopsude iibroossete muutuste tekkeks.

M. Goldberg $\left[{ }^{15}\right]$ uuris elanikkonna tervislikku seisundit tööstuspiirkonnas, kus soojuselektrijaam paiskas õhku iga päev keskmiselt 800 tonni tuhka, tõstes vaba $\mathrm{SiO}_{2}$ sisalduse atmosfäärses tolmus $22,2 \%$-le. Uuritud 322 kooliealisest lapsest (enamikus tuberkuliin-negatiivsed) konstateeriti röntgenoloogiliselt 53,5 protsendil kopsudes lapseeale mitteomaseid fibroosseid muutusi; $16,8 \%-1$ uurituist olid need iseloomult lähedased silikoosi I staadiumi puhul sedastatud muutustele. Kontrollrühma lastel, kes alaliselt elasid saastamata atmosfääriga rajoonis, ei avastatud kopsudes tolmufibroosinähte. Ka N. Janõševa [ $\left.{ }^{29}\right]$ andmetel leiti mittetuberkuloosse etioloogiaga pneumosklerootilisi muutusi lastel, kes elasid rajoonis, kus töötas üks suuremaid Nõukogude Liidu elektrijaamu. Koos suitsugaasidega paiskas see atmosfäärsesse õhku suuri lendtuhakoguseid. Tolmukontsentratsioon ōhuproovides ulatus $24,9-66,3 \mathrm{mg} / \mathrm{m}^{3}$; tolm oli peendispersne ja sisaldas kuni $15,8 \%$ vaba $\mathrm{SiO}_{2}$.

V. Nepolomski ja tema kaastöötajate $\left[{ }^{20}\right]$ andmetel sedastati fibroos-koniootilisi kopsumuutusi paljudel Sileesia tööstuspiirkondade elanikel, nii lastel kui ka täiskasvanuil, kes küll ei töötanud ei kaevandustes ega metallitööstustes, kuid elasid saastunud atmosfääriga rajoonides.

Peale mineraalse tuhatolmu satub linnade ja tööstuspiirkondade elanikel kopsudesse koos sissehingatava ōhuga veel söetolmu tahmaosakeste näol.. Kopsumuutusi, mis arenevad rohke söetolmu mitmesuguste modifikatsioonide (tahm, söe- ja grafiiditolm) pikemaajalisel sissehingamisel, nimetatakse antrakoosiks. Antrakootilised muutused võivad kujuneda ka kütuste põlemisel tekkinud tahmaga saastunud atmosiäärse ōhu pikemaajalisel sissehingamisel, misjuures, vaatamata rohkele söetolmu ladestumisele kopsukoes ja kopsuvärati lümfisōlmedes, on tolmust tingitud fibroossed muutused väga nōrgad $\left[{ }^{13}\right]$. Suhteliselt tugevamat kopsufibroosi ja emfüseemi tekitab söetolm mōnede elukutsete (nảiteks söekaevurid, katlakütjad) puhul, millal teda hingatakse sisse suurtes kontsentratsioonides $\left[{ }^{21}\right]$.

Kopsudesse sattuץ tahm pole üksnes kopsufibroosi pöhjustajaks, vaid ka tôrvolluste kandjaks. Tahmas leiduvates tôrvoilustes sisaldub aromaatseid süsivesinikke, millest mōned omavad kantserogeenset toimet. Viimastest tähtsamaks on 3,4-benspüreen.

Viimastel aastakümnetel on haigestumus ja suremus kopsuvähki märgatavalt suurenenud. Kopśuvähktõbiste arvu kasv pole tingitud mitte ainult inimeste eluvältuse pikenemisest ja kopsuvähi diagnostika paranemisest, vaid kopsuvähki haigestumise tegelikust sagenemisest $\left[{ }^{27}\right]$. Laialdaselt tsiteeritakse A. Abrikossovi ja I. Davõdovski andmeid, mis näitavad, et Nõukogude Liidu suuremates linnades on kopsuvähi esinemise sagedus, vỗrreldes vähijuhtudega teistes elundites, tõusnud $2,-3$. kohale varasemalt 5 . kohalt. Samuti 
märgib H. Druckrey [2], et reas maades, eeskätt USA-s ja Inglismaal, on haigestumine kopsuvähki märgatavalt tõusnud. Taolisi andmeid esitavad ka E. Kennaway ja R. Waller [4] Inglismaa linnade kohta.

Oheks kõige tähtsamaks kopsuvähi etioloogiliseks faktoriks peavad paljud autorid kantserogeensete süsivesinike, eeskätt 3,4-benspüreeni leidumist suitsheidistega saastatud atmosfäärses ōhus $[2,4,5,16,25,27]$. Selle faktori toimele on linnade ja tööstuspiirkondade elanikud allutatud aastakümnete vältel.

Et tahma sissehingamisega satub inimorganismi peale söeosakeste ka kantserogeenseid aineid, näitavad J. Sula [11] andmed. Ta sedastas 3,4-benspüreeni esinemist antrakootilistes kopsude lümfisōlmedes neil linnaelanikel, kes inhaleerisid pikema aja vältel suitsust ōhku. Seevastu söekaevureil, kes hingasid sisse kaevanduse tolmust ōhku, milles oli rohkesti söeosakesi, ei leitud antrakoosi puhul kopsude lümfísōlmedes 3,4-benspüreeni. Seega tõestavad J. Sula katsed, et suitsuse (s. o. kütuse mittetäieliku pōlemise produkte sisaldava) atmosfäärse ōhu sissehingamisel loob kopsudes kujunev tahmaosakeste ladestumine organismis kantserogeensete ainete depoo, mis võib osutuda keemilise kantserogeneesi allikaks.

V. Serebrennikovi $\left[{ }^{23}\right]$ andmeil märgivad Mills (Chicago) ja Pybus (Inglismaa) otsest seost kopsuvähki haigestumise kõrge taseme ja linnaõhu tolmususastme vahel.

N. Tomsoni [25] järgi on tahma lubatud piirkontsentratsiooniks atmosiäärses õhus $0,05 \mathrm{mg} / \mathrm{m}^{3}$ sel juhul, kui tolm sisaldab keskmiselt $1 \%$ tõrvolluseid, milles leidub 3,4-benspüreeni mitte üle $0,0001 \%$. Sellise tahma- ja tōrvollustesisalduse korral satuks N. Tomsoni kalkulatsioonide järgi inimese kopsudesse ööpäevas 0,0000001 mg 3,4-benspüreeni, milline annus on autori arvates inimesele praktiliselt kahjutu.

Jälgides mitmete linnade ja tööstuspiirkondade atmosfäärses ōhus leitud tōrvolluste ja 3,4-benspüreeni andmeid selgub, et nende sisaldus on lubatud piirkontsentratsioonist sageli palju kōrgem. B. Gurinovi ja ta kaastöötajate $\left[{ }^{16},{ }^{27}\right]$ uurimused näitasid, et Moskva, Ivanovo ja Groznõi linnade atmosiäärse tolmu proovides ja küttesüsteemide suitsheidistes avastati 3,4-benspüreeni. Törvolluseid leiti aspiralsioonimeetodil kogutud öhuproovides $3-12 \%$. Benspüreenisisaldus tōrvolluste proovides oli keskmiselt $0,001 \%$, harvemini kuni $0,01 \%$. 3,4-benspüreeni hulk atmosfäärist kogutud tôrvollustes osutus nimetatud autorite andmetel madalamaks kui samades linnades otse korstnast väljuvas tahmas avastatud 3,4-benspüreeni sisaldus. Viimane oli enamasti $0,01 \%$. See erinevus benspüreenisisalduses sōltub asjaolust, et atmosfääris sisalduvad 3,4-benspüreen jt. süsivesinikud aja jooksul ōhuhapniku ja valguse toimel hapenduvad, mistōttu nende hulk väheneb. Korstnast väljuva tahma uurimise! selguski, et ōhu saastumine benspüreenist ei sõltu mitte niivōrd kasutatava kütuse liigist kuivõrd tema põletamise režiimist. Mida täielikum on kütuse pōlemine, seda vähem tekib kantserogeenseid aineid.

P. Dikuni, L. Sabadi ja V. Norkini ${ }^{\left[{ }^{18}\right]}$ uurimistööde andmed 3,4-benspüreeni sisalduse kohta mitmetest Leningradi rajoonidest 1956. aastal vōetud lumeproovides näitasid selle kantserogeense aine leidumist linna köikides rajoonides. Väiksemaid benspüreeni hulki leiti linna parkide rajoonis, kus teda $1 \mathrm{~m}^{2}$ pinnasele langes poole aasta vältel $0,2 \mathrm{mg}$. Linna tööstusrajoonides esines benspüreeni $11-14$, isegi kuni 39 korda rohkem. L. Sabadi $\left[{ }^{27}\right]$ andmetel võib aga mõnedel erandjuhtumitel benspüreeni paiskuda õhku sellistes kogustes, mis tunduvalt ületavad Leningradi kohta toodud näitajaid. Nii langes Makejevkas vananenud tüüpi koksiahjudega tehaste rajoonis 5-9 mg 3,4-benspüreeni $1 \mathrm{~m}^{2}$ pinnase kohta ühe ööpäeva vältel. L. Sabadi $\left[{ }^{27}\right]$ poolt refereeritud andmetel on välismaa tööstuslinnade atmosfääris leitud kantserogeenseid süsivesinikke samasugustes või veidi suuremates kogustes kui NSV Liidu linnades.

Eespool toodud landmed ōhku saastavate elementide kahjuliku toime kohta inimorganismi (kopsufibroosi ja kopsuvähi oht) näitavad, kuivõrd hädavajalikuks osutub linnade ja tööstuspiirkondade atmosfäärse ōhu saastumise vastu võidelda.

Nõukogude Eesti linnades ja tööstuspiirkondades, eriti Tallinnas ja põlevkivi tootmise ning ümbertöötamise rajoonides kasutatakse laialdaselt kohalikku kütust - põlevkivi, 
Põlevkivi üheks iseärasuseks, võrreldes teiste kütustega, on rikkalik mineraalosadesisaldus ja põlevosa lendaineterohkus. N. Tomsoni $\left.{ }^{26}\right]$ andmetel on põlevkivi põlevosas $70-83 \%$ lenduvaid süsivesinikke, kuna neid pruunsöe põlevosas on kuni $3 \%$ ja antratsiidi põlevosas $2-5 \%$. Rohke lenduvate süsivesinikkude sisaldus põlevkivi orgaanilises osas on üheks asjaoluks, miks tema põletamisel harilikkudes küttekolletes tekib palju tahma, tõrvolluseid jm. mittetäieliku põlemise produkte. Suure mineraalosadesisalduse tõttu tekib põlevkivi põlemisel rohkesti tuhka (A. Aarna jt. [1] järgi $45-70 \%$ põlevkivi kaalust). Tuhk, raskendades põlemisprotsessis õhuhapniku juurdepääsu kütuse pōlevosale, omakorda soodustab põlevkivi mittetäielikku põlemist.

Eesti põlevkivitööstusrajoonide latmosfäärse õhu tugev saastumine tahma ja tuhaga on üldtuntud. Faktilisi andmeid selle kohta on käesoleva ajani veel vähe. 1949. a. leidis $N$. Tomson $\left.\right|^{24}$ ] põlevkiviküttel töötava Tallinna elektrijaama lähedalt sedimentatsioonimeetodil kogutud atmosfäärse tolmu proovides kõrge protsendi $(5-10 \%)$ tōrvolluseid, mis sisaldasid 3,4-benspüreeni (hulka pole antud).

Teatava ülevaate õhu saastumise kohta Kohtla-Järve ja Kiviõli põlevkivitööstuste rajoonides annavad E. Vagase $\left[{ }^{14}\right]$ uurimistulemused, mis näitavad, et Kohtla-Järve uue elektrijaama 3 korstnat paiskavad ööpäeva jooksul atmosfääri 75 tonni lendtuhka. Põlevkivituhk sisaldab ligikaudu $30 \%$ räniühendeid (kvartsi ja silikaate). Seega paiskab uus elektrijaam

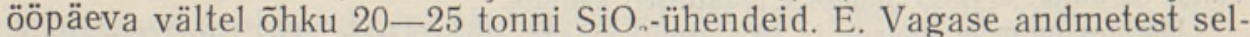
gub, et Kohtla-Järve ja Kiviõli põlevkivitööstuste ümbruses on ōhu tolmusus suurem, kui seda lubavad sanitaarsed eeskirjad.

Kirjanduses ei ole seni leidunud eksnerimentaalseid ega kliinilisi andmeid platoloogiliste protsesside kohta, mis arenevad organismis põlevkivi põletamisel tekkivate tahkete suitsheidiste (tahma ja lendtuha) toimel. Arvestades nii põlevkivi laialdast kasutamist kütusena kui ka tema iseärasust anda suitsheidistena rohkesti mittetäieliku põlemise produkte ia lendtuhka, iseäranis põletamisel harilikkudes küttekolletes, osutub põlevkivitahma ja -lendtuha patogeense toime uurimine aktuaalseks ning vajalikuks.

Põlevkivitahma ja -lendtuha patogeensuse väljaselgitamisel püüdsime morfoloogilise uurimise varal anda vastust kahele küsimusele:

1) kas põlevkivitahma ia -lendtuha segatolmu inhaleerimine tekitab katseloomade (valgete rottide) kopsudes pneumokoniootilisi muutusi;

2) kuidas avaldub põlevkivitahma kantserogeenne aktiivsus krooniliste katsetega nahakasvajate tekitamise puhul valgetel hiirtel.

\section{Materjal ja metoodika}

Katseteks vajalikku põlevkivitahmast ja -lendtuhast koosnevat segatolmu saadi põlevkiviküttel töötava Tallinna V. Kingissepa nimelise Tselluloosi ja Paberikombinaadi katlamajast korstna multitsükloni alt. Kirjanduse andmetel $\left[{ }^{16}\right]$ ei ole tahmal, mida püütakse korstnast väljapaiskel, teistsugust koostist ega sisalda ta vähem kantserogeenseid süsivesinikke kui see tahm, mis sadestub korstnas. Neil kaalutlustel valitigi katsete jaoks korstnas sadestunud tahm ja lendtuhk, mille kättesaamine oli märksa lihtsam kui korstriast väljuvate tahkete suitsheidiste püüdmine aspiraatoritega.

Tallinna Polütehnilise Instituudi anorgaanilise keemia kateedris tehtud keemilise analüüsi andmetel sisaldas katseteks kasutatud põlevkivitahma ja -lendtuha segatolm $7,9 \%$ orgaanilisi ja $92,1 \%$ anorgaanilisi ühendeid. Seotud ja vaba $\mathrm{SiO}_{2}$ üldhulk oli $33,3 \%$, vaba $\mathrm{SiO}_{2}$ sisaldus $7,6 \%$. Leningradi MTA Onkoloogia Instituudis P. Dikuni poolt teos- 
tatud spektraal-fluorestsentsanalüüsi andmetel sisaldas kasutatud segatolm $0,0014 \%$ 3,4-benspüreeni. Osakeste suuruselt oli põlevkivitahma ja -lendtuha segatolm peendispersne: $90 \%$ tolmuosakestest olid suurusega kuni $2 \mu$.

Katsed nimetatud segatolmu inhaleerimiseks korraldati dünaamilises tolmutuskambris 51 valge rotiga. Katseloomad viibisid tolmutuskambris 6 -9 kuu vältel iga päev 4 tundi, välja arvatud puhkepäevad.

Tolmukontsentratsioon, mis määrati gravimeetrilisel meetodil, oli tolmutuskambri ôhus kolmel esimesel katsekuul keskmiselt $964 \mathrm{mg} / \mathrm{m}^{3}$. Alates 4. katsekuust vähendati seda kogust keskmiselt $325 \mathrm{mg} / \mathrm{m}^{3}$ peale.

51 valgest rotist suri 9 kuud kestnud katseperioodil 17 rotti (1. katsekuul 2 rotti, 2. kuul 1 rott, 3. kuul 3 rotti, 4 . kuul 1 rott, 5. kuul 2 rotti, 6 . kuul 4 rotti, 7 . kuul 2 rotti, 8. kuul 1 rott ja 9 . kuul 1 rott). Tolmutamisperioodi elasid üle 34 valget rotti, kellest pooled inhaleerisid tolmu 6 kuu kestel ja teised 9 kuu kestel. Pärast tolmutamise lõpetamist jälgiti katseloomi kuni nende loomuliku surmani.

Kuus kuud tolmutuskambris pōlevkivitahma ja -lendtuha segatolmu inhaleerinud 17 valget rotti surid mitmesuguste ajavahemike järel pärast tolmu inhaleerimise lōpetamist (1-11 kuu jooksul). 9 kuud sama segatolmu inhaleerinud 17 valget rotti surid 1-8 kuu möödumisel, arvestades inhaleerimise lõpetamisest.

Tolmutamisperioodil surnud valgetel rottidel jälgiti segatolmust tingitud kopsumuıtuste dünaamilist arenemist. Tolmutamisjärgsel perioodil surnud rottidel vaadeldi kopsude tolmust puhastumist ja tolmust pōhjustatud kopsumuutuste sugenemist.

Kontrollrotte, kes tolmu ei inhaleerinud, oli 10.

Pneumokoniootilise ja vôimaliku kasvajalise protsessi väljaselgitamiseks uuriti valgetel rottidel mikroskoopiliselt kopse, bronhe ja kopsude regionaalseid lümfisōlmi. Uurimiseks võetud koeline materjal fikseeriti $10 \%$-lises formaliinis, sisestati tselloidiini. Koelõigud värviti hematoksüliini ja eosiiniga, hematoksüliini ja pikrofuksiiniga van Giesoni järgi ja teostati lōikude hõbedaimpregnatsioon retikuliinkiududele Tibor-Papi järgi.

Kirjandusest on teada [3], et mitmesuguste tahmaliikide kantserogeensuse uurimisel osutusid vähem efektiivseks need loomkatsed, kus kopsu- või nahavähi tekitamiseks kasutati õhku saastavaid produkte vôi tahma sellisel kujul, nagu nad leidusid õhus ja korstnas. Kōige paremini saadi näidata tahmade kantserogeenseid omadusi nendest valmistatud ekstraktide abil, mida katseloomadele nahaalusi süstiti või pikema aja kestel nahale viidi $\left[{ }^{9},{ }^{17}\right]$. Tahmaekstraktide valmistamiseks on kasutatud sagedamini bensooli, harvemini eetrit vôi muud orgaanilist lahustajat.

Toetudes mainitud kirjalikele andmetele, tehtigi põlevkivitahma kantserogeensuse uurimisel lisaks inhaleerimiskatsetele ka neid katseid, kus hiirte nahale manustati pôlevkivitahma bensoolekstrakti. Viimane valmistati Soxhlet' aparaadiga. Sobivama konsistentsi saamiseks lisandati talle sulatatud vaseliini. Spektraal-fluorestsentsanalüüsi (teostanud P. Dikun MTA Onkoloogia Instituudis Leningradis) andmetel sisaldas $1 \mathrm{ml}$ pōlev-

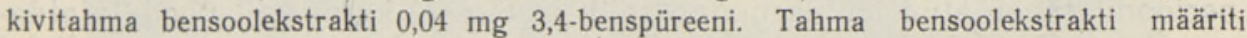
100 valge hiire nahale abaluude vahelises piirkonnas 2 korda nädalas 5 kuu 20 päeva jooksul ( 50 korral). Kontrollkatses manustati 18 valge hiire nahale bensoolvaseliini segu. Katsehiirtel jälgiti nahal kujunevaid muutusi. Täiendavaks kontrollrühmaks oli 100 valget hiirt, kellel naha määrimisi ei teostatud, kuid keda jälgiti spontaansete kasvajate $\mathrm{jm}$. patoloogiliste protsesside arenemise suhtes.

\section{Katsete tulemusi}

Katsed valgete rottidega. Kuni 9 kuud kestnud inhaleerimiskatse jooksul surnud rottide hingamiselundite uurimisel selgus, et põlevkivitahma ja -lendtuha segatolmu inhaleerimisel kujuneb valgetel rottidel pneumokoniootiline protsess.

Kõikide katsevältuste puhul avaldus suhteliselt intensiivselt tolmuosa- 
keste fagotsütoos. Valdav enamus inhaleeritud põlevkivitahma ja -lendtuha osakestest haarati koniofaagide poolt, vabu tolmukübemeid leidus alveoolide valendikes vähe. Lühema katsekestusega loomadel paiknesid koniofaagid eeskätt alveoolides. Katseaja pikenemisega rohkenes interstitsiaalses koes asuvate koniofaagide arv.

Fagotsütaarse reaktsiooni kõrval täheldati lühema katsevältusega (kuni 4 kuud) loomadel tolmu inhalatsioonist tingitud varajaste kopsumuutustena bronhide ja koldeti ka lalveoolide katarraal-deskvamatiivset protsessi. Katarraalset bronhiiti esines ka pikemate katsevältuste puhul.

Tolmukollete moodustumine põlevkivitahma ja -lendtuha inhaleerimisel kujunes aeglaselt. Alles 5. katsekuust lalates leidus kopsukoes väheldasi tolmukoldeid koniofaagidest ja vabadest tolmukübemetest, mis paiknesid peamiselt perivaskulaarses koes ja alveoolide vaheseintes, põhjustades viimaste ebaühtlast jämenemist (joon. 1). Infiltratiiv-proliferatiivne reaktsioon (lümfo-histiotsütaarsete rakuliste elementide kogunemise ja fibroblastide rohkenemise näol) tolmu ladestumisele ei olnud intensiivne ja avaldus ka pikemate katsevältuste puhul tagasihoidlikult. Tolmukollete ümber mõõdukalt rohkenenud rakuliste elementide vahel leiti 5.-9. katsekuul retikuliinkiududest võrgustikku. Sama katsekestusega loomadel täheldati emfüsematoosseid muutusi.

Inhaleeritud segatolmu eemaldumist bronhogeensel teel näitas tolmu sisaldavate koniofaagide leid hingamisteedest (bronhioolidest ja suurematest bronhiharudest), mis väljendus eriti lühemate katsevältuste (kuni 5 kuud) puhul. Et suur osa kopsu sattunud põlevkivitahma ja -lendtuha segatolmu eemaldub kopsukoest lümfisüsteemi kaudu, sellele viitas tolmu leid kopsude regionalalsetes lümfisōlmedes. Tolmu ladestumine lümfisōlmedes suurenes katsevältuse pikenemisega.

Katsetest rottidega, kes inhaleerisid põlevkivitahma ja -lendtuha segatolmu 6-9 kuud ja pärast tolmutamise lõpetamist olid vaatluse all kuni 11 kuud, nähtus, et kopsud osaliselt puhastuvad nimetatud segatolmust. See väljendus tolmukollete suuruse vähenemises ja nende asetuse hõrenemises üksteise suhtes. Viimane asjaolu viitab tolmukollete osalisele taandarenemisele.

Pärast tolmutamise lõpetamist süvenesid katsealustel rottidel interstitsiaalsele pneumokonioosivormile omased muutused, kusjuures tolmust tingitud ja nōrgalt väljendunud fibroosne protsess lokaliseerus eeskätt kopsukoe alveolaarvaheseintes, samuti perivaskulaarses ja peribronhiaalses koes (joon. 2). Vahelduvalt aladega, kus interstitsiaalne kude tolmu ladestumise tõttu fibroosselt oli paksenenud, leidus kopsukoe piirkondi krooniliste emfüsematoossete muutustega. Võrreldes tolmutamise lõpuperioodil täheldatud emfüsematoosseid protsesse, kujunesid need laialdasemaks neil rottidel, kes elasid pärast tolmutamist kauem. Samaealistel kontrollrottidel, kes tolmu ei inhaleerinud, väljendus emfüseem märgatavalt vähemas ulatuses.

Peaaegu kõikidel tolmu inhaleerinud ja seejärel 8-11 kuud elanud loomadel oli bronhides ja bronhioolides katarraalset ekssudaati. Tolmusisaldusega koniofaage täheldati ekssudaadis ainult osal juhtudest ja sedagi vähesel määral. Katarraalne bronhiit kōikides kopsusagarates esines katseloomadel suhteliselt sagedamini kui kontrollrottidel, kes tolmu ei inhaleerinud (viimastel sedastati bronhiiti 4-jal juhul 10-st).

Peaaegu kõigil pikemat aega jälgitud katserottidel oli regionaalsetesse lümfisõlmedesse ladestunud rohkesti pōlevkivitahma ja -lendtuha segatolmu, mis ületas tolmutamise ajal surnud rottidel täheldatud koguse.

Katsetest selgus, et vaatamata vaba $\mathrm{SiO}_{2}(7,6 \%)$ ja silikaatidesisaldusele $(25,7 \%)$ põ̉levkivitahma ja -lendtuha segatolmus, arenes intersțt- 


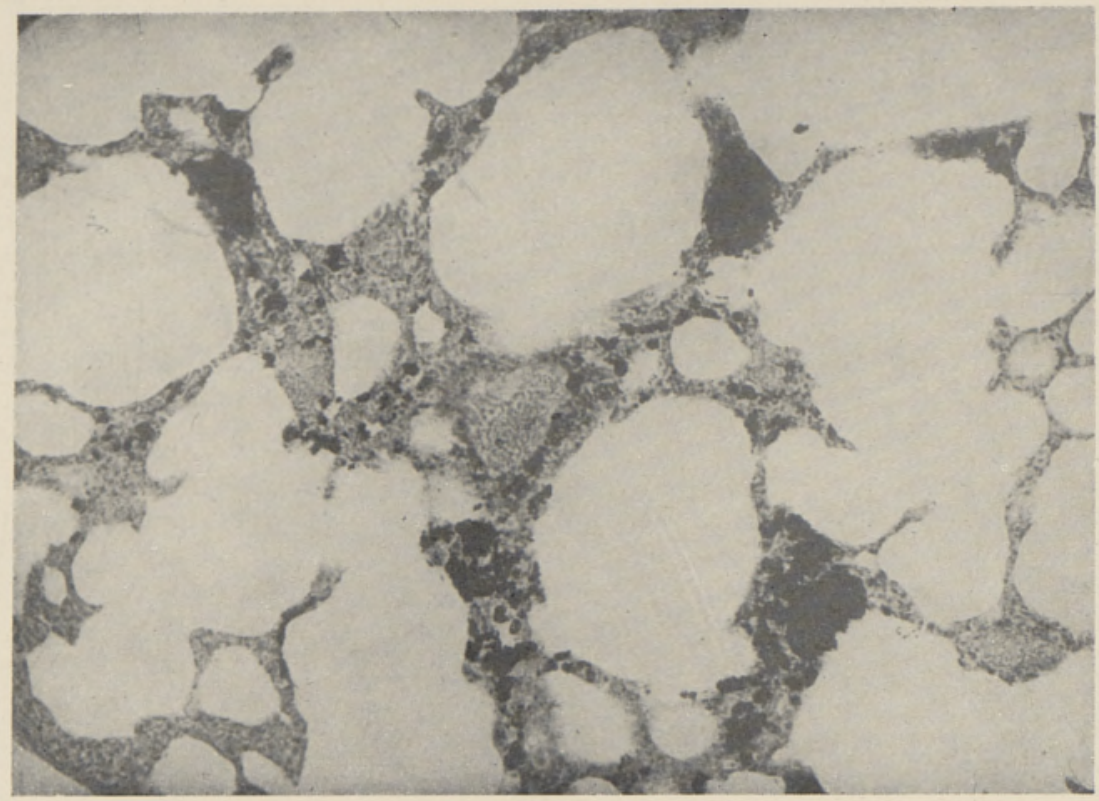

Mikrofoto 1. Tolmukolded kopsu interstitsiaalses koes valgel rotil, kes 6 kuu kestel inhaleeris põlevkivitahma ja -lendtuha segatolmu. (Suurendus $120 \times$.)

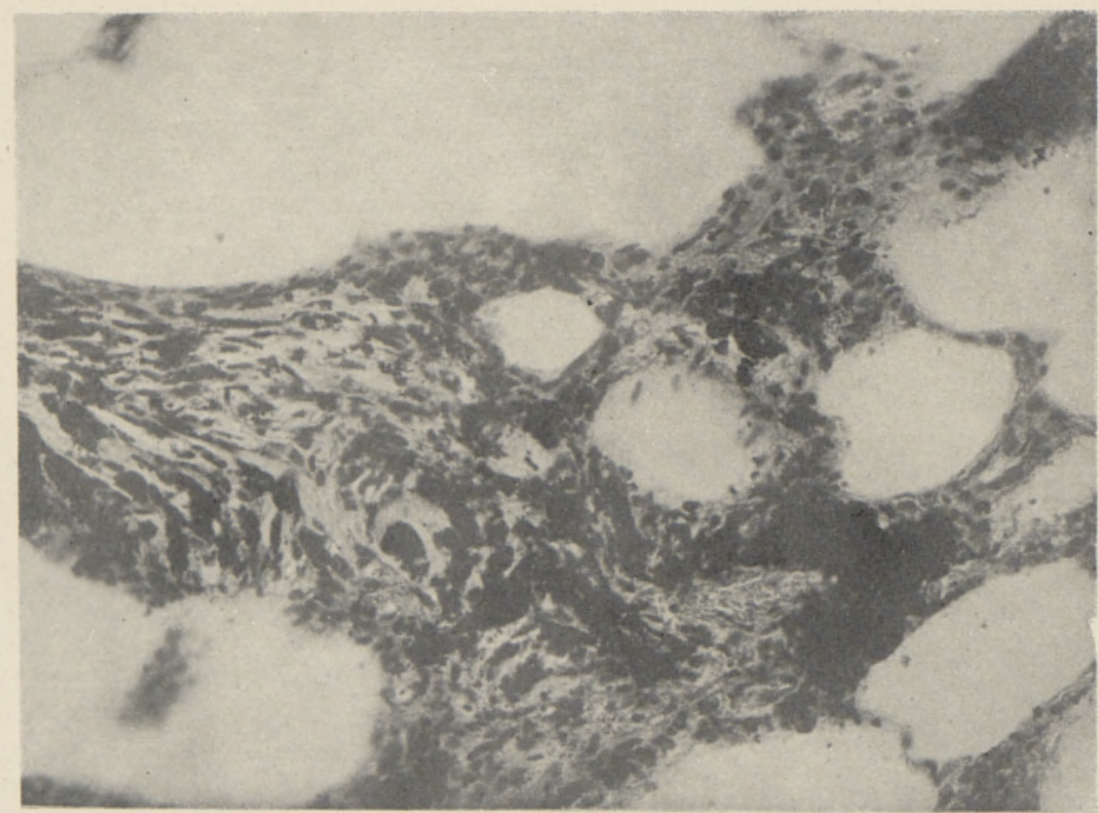

Mikrofoto 2. Tolmu ladestumisest sugenenud fibrootilised muutused kopsukoes valgel rotil, kes 9 kuu vältel inhaleeris põlevkivitahma ja -lendtuha segatolmu ning suri 6 kuu pärast, arvates tolmutamise lópetamisest. (Suurendus $250 \times$.) 


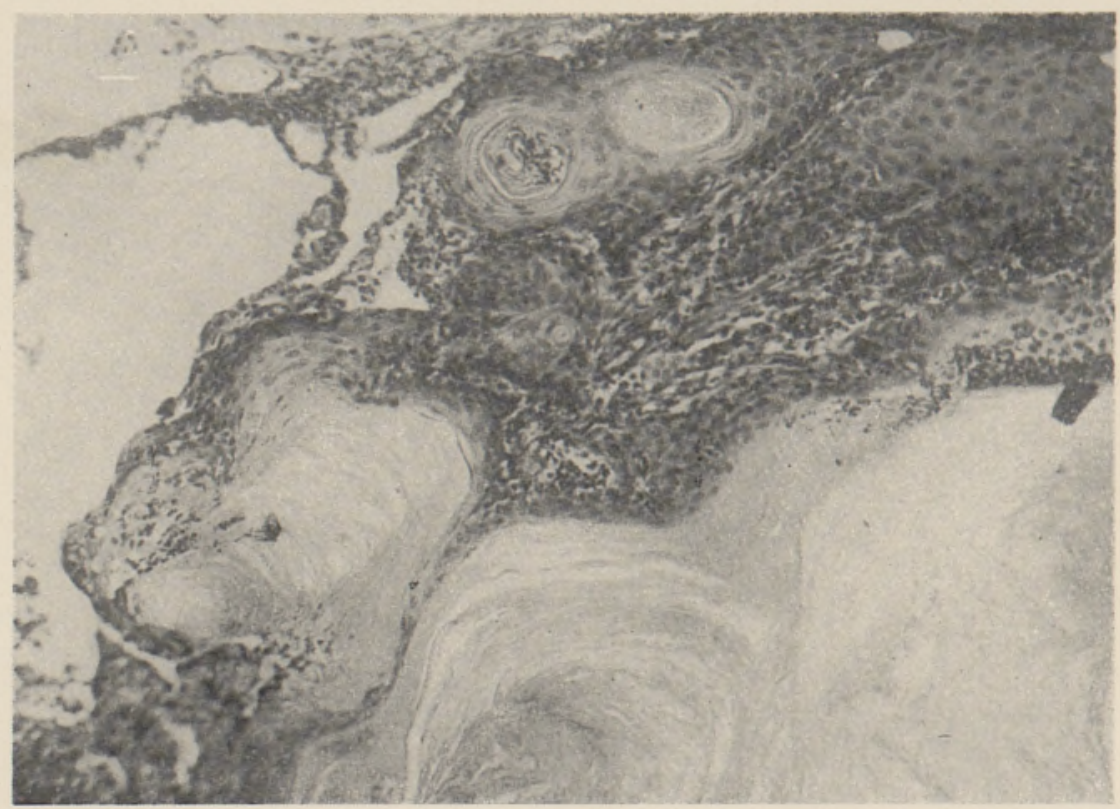

Mikrofoto 3. Sarvestuva lamerakulise vähi kolded kopsukoes valgel rotil, kes 6 kuu vältel inhaleeris pōlevkivitahma ja -lendtuha segatolmu ning suri 11 kuu pärast, arvates tolmutamise löpetamisest. (Suurendus $120 \times$.)

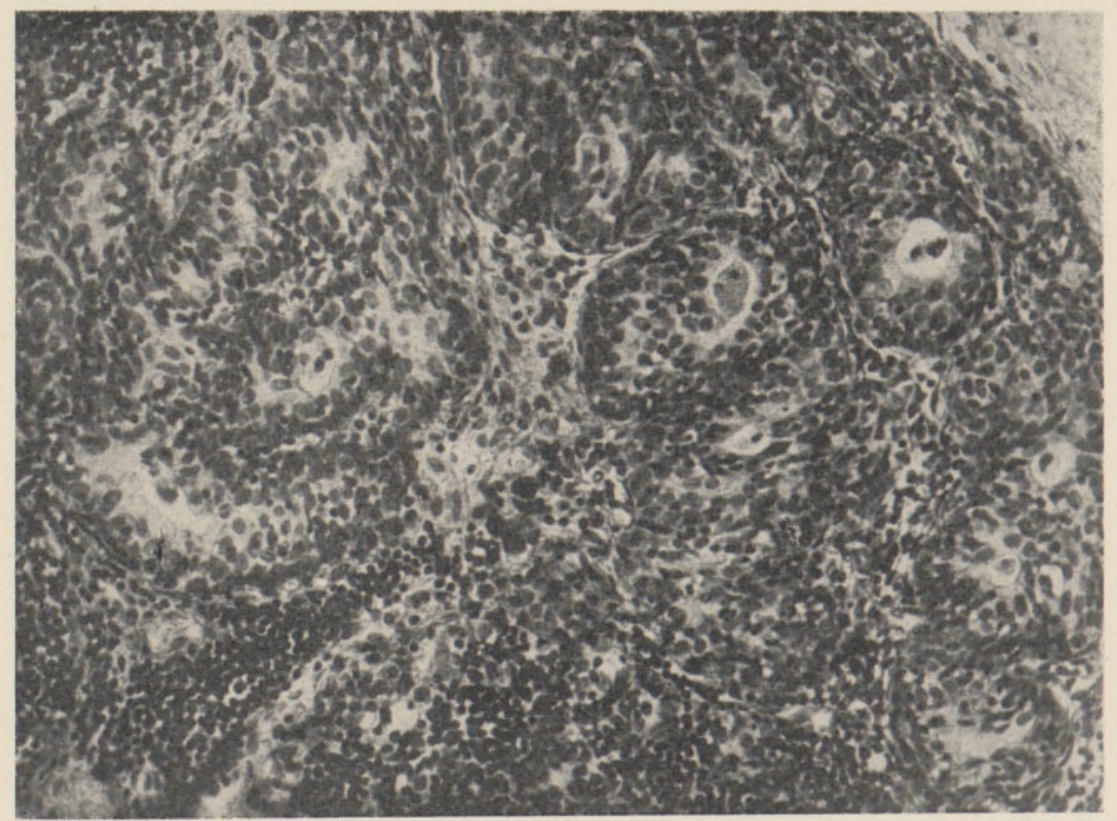

Mikrofoto 4. Kasvajaline metastaas kopsuvärati lümfísōlmes joonisel 3 näidatud vähist. (Suurendus $220 \times$.) 
siaalne pneumokoniootiline protsess selle toimel aeglaselt ja väljendus nõrgalt. Kuigi katseloomad inhaleerisid segatolmu suhteliselt suurtes hulkades, ei kujunenud nende kopsudes ulatuslikku tolmu ladestumist. See seletub eeskätt intensiivse fagotsütaarse reaktsiooniga ja suure osa tolmu eemaldumisega kopsust bronho- ja lümfogeensel teel.

Eksperimentaalsele silikoosile omast, kiiresti progresseeruvat sõlmelist produktiivset protsessi põlevkivitahma ja -lendtuha inhaleerimisest ei sugenenud.

Meie katsetes tekkinud interstitsiaalsed pneumokoniootilised muutused on üldiselt samalaadsed nendega, mida on täheldanud mitmed autorid $\left[{ }^{13,19,21]}\right.$ nii katseloomade kui ka inimeste kopsudes mõnede söemodifikatsioonide (kivisöetolm, tahm) toimel.

Peaaegu kõikidel rottidel, nagu selgus eeltoodust, leiti katarraalset bronhiiti ja bronhioliiti. Uksikutel rottidel täheldati põletikuliste muutuste foonil trahhea või bronhi limaskesta epiteeli metaplaasiat, kus ïherealine silindriline epiteel oli asendunud mitmekihilise lame-epiteeliga.

Neoplastilist protsessi kopsudes leiti ainult ühel valgel rotil, kes inhaleeris pōlevkivitahma ja -lendtuha segatolmu 6 kuu kestel ja suri 11 kuud pärast tolmutamise lõpetamist. Sellel rotil vooderdas parema kopsu ülasagara laienenud valendikuga bronhi ja bronhioole kohati üherealine silindriline, kohati mitmekihiline lame-epiteel. Metaplastilise epiteeliga ja põletikuliste muutustega bronhiharusid ümbritsevas kopsukoes leidus mitmesuguse kuju ja suurusega kasvajalisi epiteelrakulisi koldeid. Viimastest osa oli valendikkudega, mida vooderdas silindriline väheste atüpismitunnustega epiteel (adenomatoossed vohandid). Valdavam osa kasvajalistest kolletest oli umbne, koosnedes lamerakulise epiteeli tüüpi ning mõõduka atüpismiga kasvajarakkudest, mis kollete keskosas olid sarvestunud (joon. 3). Kasvajat (mis haaras enda alla $3 / 4$ ülemisest kopsusagarast) ümbritsevas atelektaatilises kopsukoes täheldati koldeti rohkesti põlevkivitahma ja -lendtuha segatolmu.

Sama looma vasakus kopsus leidus bronhiektaasiaid, kuid kasvajalisi vohandeid ei täheldatud. Parema kopsu alumises, keskmises ja aktsessoorses sagaras esines mõõdukalt väljendunud pneumokoniootiline protsess ja krooniline emfüseem.

Et käesoleval juhul parema kopsu ülasagaras avastatud muutused olid neoplastilist iseloomu, seda tõestab kasvajaliste metastaaside leid kopsude regionaalsetes lümfisōlmedes (joon. 4), kus täheldati osalt umbseid, kuid sarvestumistunnusteta, osalt adenomatoosseid, valendikuga epiteliaalseid kasvajalisi vohandeid.

Kirjanduse põhjal $\left.{ }^{8,}{ }^{10}\right]$ on teada, et spontaansed kopsutuumorid esinevad sageli inimesel ja hiirel, kuna teistel loomaliikidel, nende seas ka rotil, esineb neid harva. Bronhiaalepiteeli lamerakulist metaplaasiat, mis kujuneb sageli kroonilise bronhiektaasiatõvega vanadel rottidel A-vitamiini vaeguse korral, diagnoositakse sageli ekslikult lamerakuliseks vähiks.

Kirjandusest nähtub, et eksperimentaalse kopsuvähi (bronhiaalvähi) tekitamine rottidel õnnestub väga harva. H. Stewart'i [ $\left.{ }^{10}\right]$ andmetel läks korda põhjustada pahaloomuliste bronhiaaltuumorite arenemist rottidel, kellele viidi kopsu aerosoolina radioaktiivset tseeriumi. See on katselooma kopsus üldse üks väheseid näiteid lamerakulise vähi tekitamise kohta. Seevastu on kirjanduses rohkesti andmeid mitmesuguste kantserogeensete ainete, nende seas ka 3,4-benspüreeni sisaldavate tõrvolluste toimel adenomatoossete kopsukasvajate tekitamise kohta hiirtel.

Vastupidi neile seisukohtadele leidub kirjanduses üksikuid andmeid, mille järgi eksperimentaalse kopsuvähi tekitamine on ōnnestunud suhte- 
liselt hästi ka rottidel. Nii viitavad W. Smith $\left[{ }^{8}\right]$ ja H. Stewart $\left[{ }^{10}\right] 1924$. aastal ilmunud Mölleri tööle, kaheldes samal ajal selle tōepärasuses. Möller teatas, et tal onnestus saada lamerakulist kopsuvähki rottidel (6-el juhul 24-st), kelle nahale pikema aja vältel määriti tõrva. Kuna aga Mälleri kirjeldatud vähijuhtudel puuduvad andmed metastaaside esinemise kohta, kahtleb W. Smith $\left.{ }^{[8}\right]$ tōelise kopsuvähi esinemises ja peab Mölleri poolt kopsuvähiks arvatud vohandeid bronhide epiteeli lamerakuliseks metaplaasiaks.

Pahaloomulist kasvajat antud juhul lubab oletada selle metastaaside esinemine kopsude regionaalsetes lümfisōlmedes. Kopsuvähi sugenemise etioloogilise faktorina vōib arvestada 3,4-benspüreeni sisaldavat põlevkivitahma ja -lendtuha segatolmu, mida leidus rohkesti kasvajat ümbritsevas kopsukoes.

Meie katsed põlevkivitahma ja -lendtuha inhaleerimise kohta valgete rottide poolt näitasid veenvalt selle segatolmu pneumokonioosi tekitavat toimet. Katsed rottidega ei andnud aga selget vastust nimetatud tolmuliigi võimaliku kantserogeense toime kohta. Selle küsimuse lahendasid katsed valgete hiirtega.

Katsed valgete hiirtega. Morfoloogilisi muutusi valgetel hiirtel, kelle nahale määriti pikema aja vältel pōlevkivitahma bensoolekstrakti, on käesoleva töö autor lähemalt käsitlenud eraldi $\left[^{[2}\right]$. Hiirtel teostatud katsete tulemused tõestasid põlevkivitahma kantserogeenset toimet.

Esimesed kasvajalised moodustised leiti papilloomidena 4. katsekuul. Uldse täheldati kasvajate arenemist 58 hiirel. Katse algusest elasid üle 5 kuu 74 hiirt 100-st; kasvajate sugenemise sagedus nendel hiirtel oli $78 \%$.

Mikroskoopiliselt osutusid 58-st kasvajast 36 pahaloomuliseks (34 juhul lamerakuliseks vähiks, 2 juhul tsütoblastoomiks). Healoomulisi kasvajaid papilloomide näol esines 17 hiirel. Lisaks selgelt väljendunud hea- või pahaloomulistele kasvajatele leiti 5 juhul kasvajalisi moodustisi, kus lamerakulise vähi tunnuseid võis pidada vaid algjärgus olevaks. Kasviajalisi metastaase avastati 9 -al pahaloomuliste vohanditega hiirel (8 juhul kaenla lümfisõlmedes, ühel juhul kopsus ja kopsuvärati lümfisõlmes).

Võrdlushiirtel, kelle nahale manustati bensoolvaseliini segu, ei tekkinud kasvajalisi moodustisi. Seega ei olnud tahmaekstrakti valmistamisel kasutatud lahustajal blastomogeenset toimet.

Põlevkivitahma bensoolekstrakt ei avaldanud katseloomade organismi märgatavat üldtoksilist toimet. See selgus katsehiirte ja nende kontrollhiirte suremuse võrdlemisest, kellele nahamäärimisi ei teostatud. Kõigil katsejärkudel oli suremus enam-vähem ühesugune.

Katsed valgete rottide ja valgete hiirtega näitavad, et nii põlevkivitahm kui ka pōlevkivi-lendtuhk ei ole katseloomade organismile ohutud. Põlevkivitahmast ja -lendtuhast koosneva segatolmu inhaleerimine pikema aja vältel tekitab pneumokoniootilisi muutusi. Nii bioloogilise katse kui ka põlevkivitahma keemilise analüüsi andmetel võib kinnitada, et põlevkivitahmas leidub blastomogeenseid aineid.

Kirjeldatud katsete tulemused lubavad järeldada, et ōhku saastavad põlevkivitahm ja -lendtuhk võivad pikema aja möödudes avaldada patogeenset toimet ka inimorganismisse.

Et vältida põlevkivitahma võimalikku blastomogeenset toimet inimorganismisse ja põlevkivi-lendtuha inhaleerimisest sugenevaid pneumosklerootilisi muutusi, osutub tingimata vajalikuks võitlus atmosfäärse õhu saastumise vastu põlevkivi põletamisel tekkivate suitsheidistega, mille sisaldus atmosfäärses ōhus N. Tomsoni $\left[{ }^{24}\right]$ ja E. Vagase $\left[{ }^{14}\right]$ landmetel on märgatavalt kõrgem sanitaarsest piirkontsentratsioonist, 


\section{KIRJANDUS}

1. A a rna, A., Ka sk, K., Reier, A. ja Ö p i k, I., Pölevkivi. Tallinn, 1954.

2. Druckrey, H., Ätiologische Forschung als Grundlage einer Prophylaxe des Krebses. Oncologia, 1954, 7, Nr. 2, 1k. 155-177.

3. F a $1 \mathrm{k}, \mathrm{H}$., S teiner, P. E., The Identification of Aromatic Polycyclic Hydrocarbons in Carbon Blacks. Cancer Research, vol. 12, 1952, No. 1, 1k. 30-39.

4. Kennaway, E. L., W a 11 er, R. E., Studies of Cancer of the Lung. Acta Unionis internationalis contra cancrum, vol. 9, 1953, No. 3, 1k. 485-494.

5. Kotin, P., The Role of Atmospheric Pollution in the Pathogenesis of Pulmonary Cancer: A Review. Cancer Research, vol. 16, 1956, No. 5, lk. 375-393.

6. Pannetier, M. G., La pollution atmospherique les moyens d'y remédier. Techn. san., 1957, №. 3, lk. 73-82. Ref.: Медицинский реферативный журнал, Раздел четвертый, 1957, № 8, lk. 43.

7. Pattle, R. E., Cullumbine, H., Toxicity of Some Atmospheric Pollutants. British Medical Journal, 1956, No. 4998, lk. 913-916.

8. S mith, W. E., Lung Cancer with Special Reference to Experimental Aspects. Archives of Industrial Medicine and Occupational Medicine, vol. 5, 1952, No. 5, lk. 209-217.

9. Steiner, P. E., The Conditional Biological Activity of the Carcinogens in Carbon Blacks, and Its Elimination. Cancer Research, vol. 14, 1954, No. 2, 1k. 103-110.

10. Stew art, H., Pulmonary Tumors in Animals with Particular Reference to Mice. Acta Unionis internationalis contra cancrum, 1953, No. 3, lk. 512-528.

11. Sula, J., Anthrakosa jako možný zdroj chemické karcinogenese. Primarni rakovina plic. Praha, 1952, lk. 15-18.

12. Võ s a mä e, A., Põlevkivitahma blastomogeensest toimest. Tööhügieeni küsimusi Eesti NSV pôlevkivitööstuses, III. ENSV TA Eksperimentaalse ja Kliinilise Meditsiini Instituudi kogumik. Ilmumisel.

13. Аб рикосов А. И., Струков А. И., Патологическая анатомия, ч. II. Патологическая анатомия и патогенез болезней. М., 1954.

14. В а ган е Э. П., О степени загрязнения и мерах охраны воздуха в населенных пунктах сланцевого бассейна Эстонской ССР. Вопросы гигиены труда в сланцевой промышленности Эстонской ССР, Сб. II. Инст. эксперимент. и клинич. медицины АН Эст. ССР, Таллин, 1955, lk. 278-289.

15. Гольдберг М. С., О влиянии выбросов тепловых электростанций на здоровье детей. Гигиена и санитария, 1957, № 4, 1k. 9-15.

16. Гу р ин ов Б. П., З ор э В. А., Ил и н а А. А., Ш а бад Л. М., О содержании полициклических ароматических углеводородов в загрязнениях атмосферного воздуха и в дымовых выбросах. Гигиена и санитария, 1953, № 2, lk. $10-16$.

17. Г у р ино в Б. П., М а ш б и ц Ф. Д., Ш а б а д Л. М., Исследование бластомогенного действия некоторых смол, полученных из атмосферной пыли и при сжнгании различных видов топлива. Гигиена и санитария, 1954, № 10, lk. 12-16.

18. Дик ун П. П., Шаб ад Л. М., Норкин В. Л., Некоторые новые данные о загрязненности атмосферы промышленных городов 3,4-бензпиреном. Гигиена и санитария, 1956, № 1, lk. 6-11.

19. Жислин Л. Э., Козловски й В. С., Сенде рова Н. Я., Об антракозе как самостоятельной форме пневмокониоза. Терапевтический архив, т. XXVI, вып, 3,1954 , lk. $61-67$.

20. Неполомски й В., Соснеж М., Я ворский Я., Фиброзные изменения легких у людей промышленных областей. Patologia Polska, 1956, Nr. 2, lk. 169173. Ref.: Архив патологии, 1957, № 3, 1k. 89.

21. Р а в в и н В. А., Запыление легких в условиях шахты. Сообщение II, Патологическая анатомия фнброза легких и этиология его при профессиональном антракозе. Архив патологической анатомии и патологической физиологин, 1936, т. II, вып. 3, lk. 103-113.

22. Р язанов В. А., Санитарная охрана атмосферного воздуха. М., 1954.

23. С ер еб реннн к ов В. С., К вопросу о распространении рака легкого в Свердловске и Свердловской области. Вопросы онкологии, 1957, т. III, № 4, lk. $486-490$

24. Томсон Н. М., Загрязнения атмосферного воздуха продуктами неполного сгорания топлива и их гигиеническое значение. Гигиена и санитария, 1950, № 2 , lk. $8-12$.

25. Томсон Н. М., К вопросу о профилактике рака. Гигиена и санитария, 1951, № $11,1 \mathrm{k} .10-13$.

26. Т омсон Н. М., Об определении смолистых веществ в задымленном воздухе. Eesti NSV Teaduste Akadeemia Toimetised, II k., 1953, nr. 2, lk. 286-288.

27. Ш а 6 а д Л. М., Актуальные вопросы этиологии и патогенеза рака легких. Вопросы онкологии, т. III, 1957, № 4, 1k. 387-393. 
28. Шелейховски й Г. В., Задымление городов. Издание Министерства коммунального хозяйства РСФСР, М.-Л., 1949.

29. Я ныше в а Н. Я., Влияние загрязнения атмосферного воздуха выбросами электростанции и химического комбината на здоровье населения. Гигиена и санитария, 1957, № 8, 1k. 15-20.

Eesti NSV Teaduste Akadeemia

Eksperimentaalse ja Kliinilise Meditsiini Instituut
Saabus toimetusse

31. III 1958

\title{
О ДЕИСТВИИ СЛАНЦЕВОЙ ЛЕТУЧЕИ ЗОЛЫ И САЖИ НА ОРГАНИЗМ подопЫтных животных
}

\author{
А. И. Высамяэ, \\ кандидат медицинских наун
}

Резюме

При сжигании горючего сланца, являющегося основным местным топливом в городах и промышленных районах Әстонской ССР, образуется много золы и сажи, которые загрязняют атмосферный воздух.

С целью определения патогенности сланцевой сажи и летучей золы была предиринята попытка с помощью морфологического исследования дать ответ на следующие вопросы: 1) вызывает ли ингаляция смешанной пыли сланцевой сажи и летучей золы возникновение пневмокониотических изменений в легких подопытных животных (белых крыс) и 2) какова канцерогенность сланцевой сажи при нанесении ее в хроническом опыте на кожу белых мышей.

Белые крысы (всего 51 животное) запылялись смесью сланцевой золы и сажи в затравочной камере в течение до 9 месяцев. Концентрация пыли в камере была высокой и равнялась в первые 3 месяц в среднем $965 \mathrm{mr} / \mathrm{m}^{3}$, в следующие 6 месяцев$325 \mathrm{mr} / \mathrm{m}^{3}$. Смесь сланцевой сажи и золы содержала 7,9\% органических и $92,1 \%$ неорганических веществ. Общее содержание связанной и свободной $\mathrm{SiO}_{2}$ достигало $33,3 \%$, содержание свободной $\mathrm{SiO}_{2}-7,6 \%$. Содержание 3,4-бензпирена в смешанной пыли составляло $0,0014 \%$.

Опыты показали, что при ингаляции смешанной пыли сланцевой сажи и летучей золы у белых крыс возникает слабо выраженный пневмокониотический процесс. Начиная с 5 месяца запыления наблюдалось образование пылевых очажков из пылевых клеток и свободных пылинок. При более длительных сроках опыта (запыление сроком до 9 месяцев, а также в течение 6 и 9 месяцев с последующим наблюдением еще до 11 месяцев) у животных образовались слабо выраженные продуктивно-фиброзные изменения межуточной ткани.

У одной крысы, вдыхавшей пыль сланцевой сажи в течение 6 месяцев, а затем находившейся под наблюдением 11 месяцев, был обнаружен рак легкого с метаста. зами в регионарных лимфоузлах.

Опыты с нанесением в течение длительного времени бензольного экстракта сланцевой сажи на кожу спины 100 белых мышей доказали канцерогенность сланшевой сажи.

Результаты опытов показывают, что смешанная пыль летучей золы и сажи небезопасна для организма, и что с загрязнением атмосферного воздуха этими продуктами горения сланцев необходимо вести борьбу.

\section{Институт экспериментальной и клинической медицины Поступила в редакцию Академии наук Эстонской ССР




\section{ON THE ACTION OF OIL SHALE SOOT AND QUICKASH ON THE ORGANISM OF EXPERIMENTAL ANIMALS}

\section{A. Võsamäe}

\section{Summary}

The combustion of oil shale, which is the most particular local fuel in towns and industrial districts of Estonia, generates a great quantity of ash and soot, contaminating the environmental atmospheric air.

With the aim to establish the pathogenicity of oil shale soot and quickash, we endeavoured, by means of morphological investigation, to answer two questions: 1) whether the inhalation of the mixed dust of oil shale soot and quickash causes the generation of pneumoconiotic changes in the lungs of experimental animals (white rats) and 2) whether oil shale soot possesses the carcinogenic properties in chronic experiments with applying its bensol extracts on the skin oi white mice.

51 white rats were kept in a dynamic dusting-chamber for exposure to the inhalation of dust of oil shale ash and soot for a period of up to 9 months. The concentration of dust in the chamber was high in the first 3 months, being equal to $965 \mathrm{mg} / \mathrm{m}^{3}$. In the following 6 months the concentration of dust was $325 \mathrm{mg} / \mathrm{m}^{3}$. The mixed dust of oil shale soot and ash contained 7.9 per cent organic and 92.1 per cent inorganic substances. The general content of $\mathrm{SiO}_{2}$ was 33.3 per cent, the content of free $\mathrm{SiO}_{2}$ was 7.6 per cent. The content of 3.4-benzpyrene in the mixed dust was 0.0014 per cent.

The experiments showed that the exposition of white rats to the inhalation of mixed dust of oil shale soot and ash causes delicately expressed pneumoconiotic changes. From the beginning of the fifth month of inhalation there were found dust foci consisting of dust cells and free particles of dust. In experiments with the exposure of animals for a longer period of time to inhalation (for 9 months, and also the rats who had inhaled dust for 6 to 9 months, and thereafter were still observed for up to 11 months), there were delicate productive-fibrous changes in the interstitial tissue of the lungs.

One white rat who inhaled the dust of oil shale soot and ash for 6 months and died 11 months after the discontinuation of the exposure to dust, developed lung cancer with metastases in the regionary lymph glands.

The experiments in 100 mice with the painting of benzol extract of oil shale soot on the skin of the back proved the carcinogenicity of oil shale soot.

The results of our experiments indicated that the dust of oil shale soot and ash is not without danger to the organism, and that it is necessary to fight against the pollution of atmospheric air with the products of the combustion of oil shale.

Academy of Sciences of the Estonian S. S. R., Institute of Experimental and Clinical Medicine
Received March 31, 1958 